\title{
Article
}

\section{Projection of SDGs in Codes of Ethics-Case Study about Lost in Translation}

\author{
Adam P. Balcerzak 1,2,3,*(D) and Radka MacGregor Pelikánová ${ }^{4}$ (D) \\ 1 Department of Market and Consumption, University of Warmia and Mazury in Olsztyn, \\ pl. Cieszyński 1/327, 10-720 Olsztyn, Poland \\ 2 Department of Entrepreneurship and Management, University of Entrepreneurship and Law, \\ Vltavská 585/14, 15000 Praha, Czech Republic \\ 3 Department of Economics, Brno University of Technology, Faculty of Business and Management, \\ Kolejní 2906/4, 61200 Brno, Czech Republic \\ 4 Department of International Business, Metropolitan University Prague, Dubečská 900/10, \\ 10000 Prague 10, Czech Republic; radka.macgregor@mup.cz \\ * Correspondence: a.balcerzak@uwm.edu.pl
}

Received: 5 October 2020; Accepted: 6 November 2020; Published: 26 November 2020 updates

\begin{abstract}
The United Nations' (UN) drive for sustainability culminates in a recent milestone document, Agenda 2030, which sets forth 17 Sustainable Development Goals (SDGs). Arguably, these SDGs inspire governments more than they do individual businesses and their embracement and measurement at the business level faces a myriad of shortcomings. A case study of internal declaratory documents about sustainability and other ethical commitments, such as codes of ethics, represents a feasible platform to collect fresh and inside primary data about the projection of SDGs in these codes of ethics, and ultimately in the strategy and daily operations of involved businesses. The representativeness of the sample of 30 businesses is ensured by the size of these businesses, their inter-related nature, and significance in the EU. A holistic approach, along with meta-analysis, comparison, and a combination of automatic keyword-based content analysis and of a manual simplified Delphi-method, allows for the addressing of both underlying burning questions-(i) how SDGs are projected in these codes of ethics and (ii) why not in a perfect manner. The main five findings point out the deep conceptual misunderstandings and shortcomings by businesses, which do not properly work with their codes of ethics, and which could take at least partially the SDG's guidance. These rather pioneering propositions are not conclusive, due to the inherent and inevitable limitations of the performed case study, and need to be verified over time (longitudinally), while expanding the pool of studied codes of ethics.
\end{abstract}

Keywords: code of ethics; Sustainable Development Goals (SDGs); content analysis

\section{Introduction}

Western modern civilization is a truly complex society reflecting global competitiveness, relying on an advanced usage of information systems and information technology (IS/IT) and moving from the post-industrial stage even further (Lafferty 2019; Kisel'áková et al. 2019; Hayhoe et al. 2019; Ainsworth-Rowen 2019; Androniceanu 2019; Pickard et al. 2019). Nevertheless, its roots are intimately linked to Christianity, to Aristotelian arithmetic and geometric perceptions of justice, to the Roman law with its legal reasoning, and to the emerged common law specifics (MacGregor Pelikánová 2017a). As with each and every society and community, it requires the establishment and respect of a set of orders under the auspices of certain values, and this while working towards the common good (MacGregor Pelikánová 2017b) and organically continuing the mentioned roots. In the 1960s, in a large 
part of the Western world, there emerged a reinforced interest in social progressive values, along with political awareness under the auspices of "communitarianism" and in the 1970s this was transformed into an individualist focus marked by a set of world crises and a general move from Keynesian economic theory to neoliberal theory. This was the very setting in which the United Nations (UN) decided to step in and address the conflict between the commitment to the promotion of globalized economic growth and the issue of increasing world population needs, along with the degrading ecological situation (Meadows et al. 1972). The highly ambitious vision of the UN aimed to achieve global prosperity without environmental deterioration in the entire world (MacGregor Pelikánová 2019a) and was presented through a famous proclamation "Our Common Future-A Global Agenda for Change", prepared by the Brundtland Commission ("Brundtland Report"). The Brundtland Report was published in 1987 as the United Nations' (UN) Annex to document A/42/427 and in 1992 there followed another outcome of the UN's endeavors - the Rio Declaration on Environment and Development, and the Statement of Principles for the Sustainable Management of Forests, also known as Agenda 21. In 2015, this UN orchestrated drive reached its milestone, with a direct impact for current business conduct in the EU, the UN Resolution A/RES/71/1 “Transforming our World: The 2030 Agenda for Sustainable Development" (UN Agenda 2030) with its 17 Sustainable Development Goals (SDGs) and 169 associated targets (MacGregor et al. 2020a), based on the five Ps-an aspirational plan of action for people, planet, prosperity, peace, and partnership. This fundamental policy is recognized on international, regional, national, and even individual levels (MacGregor Pelikánová 2018; Turečková and Nevima 2019) and has a global nature with a performance framework arguably difficult to be cascaded to the sub-national and individual business level (Patel et al. 2017; Galli et al. 2018). The UN Agenda 2030 has cemented the recognition of sustainability as the key concept, not only at the international level but as well on the state level, and has led to the introduction of the multi-stakeholder model (Van Tulder 2017) and cross-sector partnership (Van Tulder et al. 2016). This leads to strong expectations that businesses will embrace sustainability and SDGs as a part of their business models (Schaltegger et al. 2018; Razminiene 2019; Mazzoni 2020), will issue their internal moral constitutions-codes of ethics (Van Tulder and Kolk 2001) _ as a general direction for their future (Zikic 2018), and ultimately will deeply engage in corporate social responsibility (CSR) (Van Tulder and Keen 2018), i.e., they will engage in a myriad of social responsibilities: economic, legal, ethical, etc. (Sroka and Szántó 2018; Belas et al. 2020). Nevertheless, there are already indices that businesses fail in making adequate provisions oriented towards SDGs (Adshead et al. 2019; Thacker et al. 2019) and ultimately the commitment to go for SDGs is falling behind, especially at the local and individual levels (Mansell et al. 2020; Metzker and Streimikis 2020).

Regarding the legislative framework, the EU reacted to the UN Agenda 2030, and the mentioned local and individual level challenges, via the updated Directive 2013/34/EU. The EU crossed the Rubicon by setting, via this Directive, a legal duty for large European businesses to include their CSR statements in their management reports, which are published as a part of their annual reports (MacGregor Pelikánová 2019a) and so to bridge pre-existing jurisdictional differences. As well, this aspect is also part of the business plans of projects for those companies that are applicants or recipients of subsidies from EU funds (Melecký and Staníčková 2014). However, the content, scope, and enforcement of this legal duty remains rather general, abstract, and vague (MacGregor et al. 2020b). Specifically, neither the EU law nor the national laws of EU member states deal explicitly with the reflection of the SDGs in these CSR statements (MacGregor et al. 2020a). In addition, the codes of ethics are basically beyond the reach of law, except the consumer and unfair competition rules prohibiting lies and misleading information in codes of ethics (MacGregor Pelikánová 2019b) and a few national law particularities, see the Italian requirements vis-à-vis codes of ethics (MacGregor Pelikánová and MacGregor 2020).

Consequently, European businesses are, via various policies, asked to embrace sustainability via CSR (MacGregor Pelikánová 2019a; Džupina and Džupinova 2019), to reflect the SDGs in their strategies as well as in their daily operations and ideally proclaim it in their code of ethics. However, this is a mere request, and it is up to each and every business whether it will issue a code of ethics 
and, if yes, whether and how it will project SDGs in such a code of ethics. Thus far, there are clear indices that sustainability and CSR are understood in a heterogenous manner-as a waste, as a source of competitive advantage, as a fundamental commitment, and a pre-requirement of (not only economically) successful operations (Girard and Sobczak 2012; Rodriguez-Fernandez 2016; MacGregor Pelikánová and MacGregor 2019). The addressing of the SDGs represents an even higher form and, due to its more complex and wordy nature, could, but does not need to, be identified in codes of ethics. Namely, it is totally up to the free discretion of businesses whether they will address SDGs in their codes of ethics and consequently will move from a negative ethical duty to avoid harm to a positive duty to do good (Van Zanten and Tulder 2018). Indeed, it is up businesses whether they will go for an SDG non-compliance, or a low compliance or a high compliance (Kolk and Tulder 2005). The projection of SDGs in codes of ethics is a result of the exercise of the freedom of will by businesses and their commitment to moral values and ethical obligations. Academia is rather optimistic and expects businesses to go for SDGs and inform the public-at-large about it and so improve the perception of the given business by (ideally all) stakeholders (Tölkes and Butzmann 2018; Krajnakova et al. 2018; Sroka and Szántó 2018; Ionescu 2019). One academic stream even proposes that this leads neither to a rivalry nor to excludability (Czyżewski et al. 2016), that it supports competitiveness (Dima et al. 2018; Paksiova 2016), and develops a competitive advantage (MacGregor Pelikánová 2019a). Sustainable entrepreneurship disclosure has positive and direct impact on firm performance increasing customer loyalty and thus increasing firms' market valuation (Mohammadi et al. 2018).

However, there are strong undertones calling this unrealistic or even fictional, and reminding us about the lack of a legal liability towards the entire society (Sroka and Lórinczy 2015). They emphasize the need for a pragmatic and often strong materialistic profit-increasing orientation of businesses (MacGregor et al. 2020a) along with the potential of the SDGs to lead to waste (MacGregor et al. 2020b) and be, ultimately, even branding-wise contra-productive (MacGregor Pelikánová and MacGregor 2020). Additionally, as it was proven by Metzker and Streimikis (2020), quite often even when the decision-makers are aware of the need or postulated long-term benefits of an ethical approach and moral implications of their decisions, in reality they are not fully familiar with the real meaning of the concepts of CSR, which undermines the possibility of its enforcement in management practice. As a result, before engaging in further elaboration, one needs to fully appreciate the complete literature review for this topic (Section 2) and, via appropriate methodology (Section 3) process the, at least theoretical, potential of codes of ethics to overlap with SDGs (Section 4) and the empirical findings about the reality of this potential and its materialization (Section 5). This should lead to both new and well-founded results to be subjected to a critical discussion (Section 6) and ultimately culminate in conclusions, while being fully aware about their inherent limitations (Section 7).

\section{Literature Review}

The effectiveness of a businesses' conduct means that the business is engaging in right things and behavior. Pursuant to Kant, the rightness of such an endeavor is determined by the character of the principle that a person or business chooses to act upon (Kant [1785] 2011). The appreciation of rightness is inherently subjective, contextual, and should not lead to an automatic rejection of the modern inclination for self-realization (Taylor 2018). Therefore, it represents an ethical call which is a subject of various appreciations and does not lead to a legal liability. Consequently, codes of ethics are a demonstration of self-imposed regulations by their subjects; their modern era dates back to the Great Depression (McDonald 2009) and the milestones of this era are various crises and scandals, such as the 2002 events leading to the Sarbanes Oxley Act (Cerchia and Piccolo 2019). Although codes of ethics have even a meta-ethical dimension and represent a self-regulation which is not legally binding (Babri et al. 2019), their violation may lead to certain sanctions and other negative consequences, such as a lack of personal appraisal or negative publicity (Kaptein 2011; Oladinrin and Ho 2016).

Currently, codes of ethics are either general and abstract (typical codes of ethics) or more specific and practical and detail oriented (atypical codes of ethics, also known as codes of conduct). They are 
multifunctional, proclaim moral principles and values, and impose not enforceable moral duties which are important to (some) stakeholders (Hoover and Pepper 2015; Adelstein and Clegg 2016). Such codes of ethics are expected from, but not limited to, large businesses (Linnhoff et al. 2014; Kot 2018) and their publication is more or less a must (Statler and Oliver 2016; Desai and Roberts 2013). Indeed, over $90 \%$ of businesses belonging to the Fortune US 100 and Fortune Global 100 publish their codes of ethics (Babri et al. 2019) and statistically the values most frequently mentioned by them are: credibility, respect, responsibility, honesty, care, and citizenship (McDonald 2009). Exactly these values should create a moral compass to be employed while assessing the reality and feasibility (Weber and Wasieleski 2013) and arguably should steer the business towards productivity, a reduction of losses, an increase in trustworthiness, development of customer loyalty, and maintenance of a successful team of employees, and ultimately the cultivation of an ethical business environment (Singh et al. 2012; Nicolaides 2016).

The most recent trend points to the growing importance of sustainability along with the SDGs, the CSR, and of codes of ethics (Haessler 2020) and the implied multi-stakeholder model and collaborative partnership (Pisani et al. 2017; Van Tulder and Keen 2018; Kot et al. 2018), and this at both the local and individual business levels (Sachs 2012; Sachs et al. 2016; Semenenko et al. 2019; Horská et al. 2019; Khan et al. 2019). At the same time, it must be emphasized that the UN Agenda 2030 with 17 SDGs came as a global response to the Planetary Boundary Challenge, i.e., its roots go back to UN Millennium (eight) Goals from 2000 (Sachs 2012) and the Swedish concept of nine planetary boundaries from 2009 (Rockström et al. 2009; Steffen et al. 2015). Consequently, 17 SDGs are a major challenge in the implementation of the global sustainability agenda (Sosik and Jung 2018) and, unlike their precursor, the 8 Millennium Goals, they are truly global, i.e., for both developed and developing countries, and fully pursuant to the multi-stakeholder model and bottom-to-top approach (Mansell et al. 2020). This leads to some tension, because SDGs are made at the highest international level, but materialized at the lowest local and individual levels (Adshead et al. 2019; Thacker et al. 2019; Vu and Ngo 2019). Arguably, SDGs are "overly universal", broadly framed, inconsistent, and difficult to quantify, implement, and monitor (Bali Swain and Yang-Wallentin 2019). It is even argued that there is a gap between the perception and engagement with SDGs on these extreme levels (Haessler 2020; Mansell et al. 2020) and that the CSR might get crippled by that and fail to pursue the creating shared values (CSV) as championed by leading, not only academic, authorities (Porter and Kramer 2011). A new academic stream even proposes that sustainability is "a function of values" (Rickbaby et al. 2020) and that a proper selection and communication of these values to stakeholders is absolutely pivotal (Di Maddaloni and Derakshan 2019). This leads to an even stronger call to understand these highly complex SDGs and it is highly instructive to overview them while keeping in mind their 169 targets and 244 individual indicators, as shown in Table 1.

Table 1. Selective overview of 17 Sustainable Development Goals (SDGs) with 169 targets and 244 indicators.

\begin{tabular}{|c|c|c|}
\hline SDG (Keywords Highlighted) & Target by 2030 & Indicator \\
\hline 1. End poverty ... everywhere & 1.2. Reduce $50 \%$ people in poverty & Proportions of population \\
\hline 2. End hunger ... sustainable agriculture & 2.1. End hunger & Undernourishment \\
\hline 3. Ensure healthy lives ... well-being & 3.3. End pandemics HIV, TBC & Number of infected \\
\hline 4. Ensure inclusive equitable education. & 4.1. Education for boys, girls & Entry rate, success rate \\
\hline 5. Achieve gender equality & 5.1. End of all female discrimination & Violence, marriage under 15 \\
\hline 6. Availability ... sustainable water & 6.1. Water for all & Safely managed water \\
\hline 7. Access to affordable sustainable energy & 7.1. Universal access to energy & Access to electricity \\
\hline 8. Inclusive sustainable economic growth & 8.1. $7 \%$ GDP growth in undevel. & Annual growth GDP/capita \\
\hline 9. Sustainable industrialization innovation & 9.5. Enhance scientific research & $\mathrm{CO}_{2}$ emission, high tech \\
\hline 10. Reduce inequality ... among countries & 10.1. Income growth of the $40 \%$ & Growth rates of income \\
\hline 11. Sustainable human settlements safe & 11.1. Upgrade slums & Proportion of urban pop. \\
\hline 12. Sustainable consumption ... production & 12.2. Sustainable management & Material footprint \\
\hline 13. Action to combat climate change & 13.2. Climate changes policies & Greenhouse emission/year \\
\hline 14. Sustainably use the oceans, seas, ... & 14.7. Sustainable use marine & Sustainable fishery \\
\hline 15. Sustainable use of terrestrial ecosystem & 15.3. Combat desertification & Proportion of degraded land \\
\hline 16. Peace, access to justice for all & 16.3. Promote rule of law & Unsentenced detainees \\
\hline 17. Global Partnership for Sustain. Dev. & 17.1. Domestic resource mobilization & Total govt revenue/GDP \\
\hline
\end{tabular}


This selective overview clearly demonstrates the heterogeneity and dramatically different nature of SDGs, as well as a strong ethical background of certain SDGs. Exactly these SDGs are primary candidates to be explicitly and expressly included in codes of ethics, see e.g., SDG 5, 9, 12. This matches up with the often-repeated proposition that codes of ethics should reflect the sustainability with SDGs and be the foundation for a future world which will fairly and sustainably balance economic, environmental, and social factors (Zikic 2018) in the context of a highly competitive knowledge economy (Dima et al. 2018). Despite all potential shortcomings of a possible study of the projection of SDGs in codes of ethics, it must be admitted that even anecdotical data in this respect is highly valuable, because the very needed measuring of SDGs is notoriously fraught with challenges (Bali Swain 2018). Even, there are objections that SDGs are encyclopedic and where everything is labelled "top priority", then at the very end of the day, actually nothing is a priority (Easterly 2015). Ultimately, only a small stream of literature has recently addressed this burning issue of measuring and monitoring SDGs (Sachs et al. 2016; Spaiser et al. 2016). Hence, the contribution of codes of ethics and their studies seem prima facie relevant. However, it must be admitted that the role of codes of ethics to influence decision making and, ultimately, the ethical and sustainable behavior of the business is not so large as popularly believed, i.e., codes of ethics might have rather little than big impact on decision processes of the particular business (Lere and Gaumnitz 2003). In sum, SDG reporting and integration of SDGs in business policies and strategies are rather complex and subject of an ongoing debate of both academia and practice (Idowu et al. 2019; Onyango and Ndege 2020). There are voices correctly pointing out that codes of ethics, as well as the perception of the SDGs, need to be appreciated from the perspective of the large and heterogeneous group of stakeholders, which can be both internal (Zolingen and Honders 2010; Fatemi et al. 2018; Harymawan et al. 2020), as well as external, such as local authorities and governments (Erwin 2011; Miłek 2018; Wattanakuljarus 2019). Indeed, the moral maturity of stakeholders varies significantly, and this is even across the same jurisdiction (Messikomer and Circa 2010; Vogel 2010; Cerchia and Piccolo 2019) and even the very same business (Perez-Batres et al. 2012). It must be remembered that transition to sustainability is often costly and in need of massive investments. As a result, private investments may be not so keen on sustainability since such investments are at least from the short time perspective financially unattractive (Sokolovska and Kešeljević 2019). Such tensions might be ill-conceived and contra-productive as well, since it can induce an organizational commitment to the desired SDG (Arora et al. 2020) and add to the profitability criterion, as well other criteria linked or not all linked to the business conduct per se, such as helping minorities and supporting human rights (Clark et al. 2016).

Well, right now, it needs to be humbly admitted that scientists and academics know very little about this perception, process, and mechanism of the projection of SDGs in codes of ethics (Washburn et al. 2018). Further, codes of ethics combine economic and moral language (Whitehouse 2010). Therefore, this complex plethora needs to be both theoretically and empirically analyzed while employing an appropriate methodology.

\section{Materials and Methods}

The materials and methods used are directly determined by the two interrelated purposes of this paper, i.e., by the need to academically robustly address two questions-(i) how SDGs are projected in codes of ethics, i.e., in what manner 17 SDGs get reflected by pre-selected codes of ethics and (ii) why not in a perfect manner. The provided literature review reveals the complexity and multi-level differences in the approach to SDGs and an indication that their measurement and achievement by 2030, especially at the level of local and individual businesses, is highly questionable (Mansell et al. 2020), despite a reasonable awareness of them and their relevancy for businesses. This organically leads to a call for a case study, specifically, case studies. Considering the moral and ethical foundations as the common denominator, the incorporation and embracement of SDGs by businesses is observed by their codes of ethics. To put it differently, codes of ethics, as self-imposed manifestations of moral principles and values, are the prima facie place where businesses should consider SDGs. In order to achieve 
representativeness and homogeneity while offering a comparative aspect, 30 large businesses from Central Europe which have published their codes of ethics were selected. The first group consists of 20 Czech large businesses, i.e., businesses selected from the pool of 35 Czech businesses with the largest annual revenues in 2018 and which have published their codes of ethics on their Internet domains. Namely, these 20 businesses are the largest Czech businesses with publicly available codes of ethics. The year 2018 was selected because, due to the COVID-19 measures, some businesses have not yet filed their financial and non-financial reports for 2019 and/or these reports have not yet been published. Although each of these 20 Czech businesses have over 500 employees, they differ dramatically in their assets (between CZK 10 billion and CZK 600 billion) and in their net income (from negative values to over CZK 20 billion). Table 2 provides key identification information about these businesses.

Table 2. Case study—first group—-the largest Czech business with codes based on revenue in billion CZK.

\begin{tabular}{rcccc}
\hline & Business & ID & Industry & R. bil. CZK \\
\hline 1. & Škoda Auto, a.s. & 00177041 & automobiles & 416 \\
2. & ČEZ, a.s. & 45274649 & electricity & 185 \\
3. & Agrofert, a.s. & 61672190 & agricultural & 160 \\
4. & Energetický a Prümyslový Holding, a.s. & 28356250 & energy & 160 \\
5. & UNIPETROL, a.s. & 61672190 & chemicals & 130 \\
6. & RWE Supply \& Trading CZ a.s. & 26460815 & oil and gas & 104 \\
7. & Foxconn Technology CZ, s.r.o. & 27516032 & electronics & 104 \\
8. & Continental Automotive CZ s.r.o. & 62024922 & automobiles & 57 \\
9. & Kaufland Česká Republika, v.o.s. & 25110161 & grocery & 57 \\
10. & Albert Česká repulika, s.r.o. (Ahold) & 44012373 & grocery & 49 \\
11. & ČEPRO, a.s. & 60193531 & oil and gas & 48 \\
12. & Finitrading a.s. (Třinecké želez.) & 61974692 & iron, finance & 47 \\
13. & MOL Česká republika, s.r.o. & 49450301 & gas & 50 \\
14. & E.ON Česká republika, s.r.o. & 25733591 & energy & 45 \\
15 & O2 Czech Republic a.s. & 60193336 & telecom. & 38 \\
16. & České Dráhy, a.s. & 70994226 & railways & 35 \\
17. & Metrostav a.s. & 00014915 & building & 35 \\
18. & VEOLIA ČESKÁ REPUBLIKA, a.s. & 49241214 & water supply & 27 \\
19. & T-Mobile Czech Republic a.s. & 64949681 & telecom. & 14 \\
20. & Skanska, a.s. & 26271303 & building & 14 \\
\hline
\end{tabular}

Prepared by the authors based on justice.cz and Internet domains of businesses.

The second group consists of large European businesses which are directly related to Czech businesses from the first group, typically by being in the same holding group, and at the same time which have published their codes of ethics on their Internet domains. Namely, each of these 10 businesses is a business from an EU member state, different from the Czech Republic, which is a member of the same holding group as a Czech business from the first group, see Table 3.

Table 3. Case study—second group—large European businesses related to Czech business from the first group.

\begin{tabular}{ccccc}
\hline & European Business & Country & Industry & Related to \\
\hline 21. & Ahold Delhaize & NL & grocery & Albert \\
22. & Continental AG & GE & automobiles & Continental \\
23. & Deutsche Telekom AG & GE & telecom. & T-Mobile \\
24. & Mol Group & HU & gas & MOL ČR \\
25. & Orlen Polski Koncern Naftowy SA & PL & chemicals & Unipetrol \\
26. & RWE Group & GE & oil and gas & RWE \\
27. & Skanska Group HQ & SW & building & Skanska \\
28. & Telefónica & SP & telecom. & O2 \\
29. & Veolia & FR & water supply & Veolia \\
30. & Volkswagen Group & GE & automobiles & Škoda \\
\hline \multicolumn{4}{c}{}
\end{tabular}

Therefore, the representativeness of the sample of 30 businesses is ensured by the size of these businesses, their inter-related nature, and significance in the EU. Their codes of ethics were located and downloaded from their official Internet domains. 
It is pivotal to take a holistic approach to these codes of ethics, along with meta-analysis (Silverman 2013) and the intrinsic, as well as extrinsic, descriptive analysis, while using a combination of text analysis, also known as content analysis (Kuckartz 2014), which makes replicable and valid inferences about texts and is considered an established research method, even with respect to business ethics and CSR issues (MacGregor Pelikánová 2019b). The meta-analysis is the technique par excellence for the pre-selected and performed study, because it is founded upon the conviction that more information is available than conventionally admitted and realized (Glass 1976; Schmidt and Hunter 2014), especially considering the scientific model of both direct and indirect causality (Heckman 2005a, 2005b) and exactly this applies to the study of codes. The selected advanced text analysis complementarily involves content quantitative and qualitative methods and consequently allows the addressing of both underlying burning questions in the case study format. The interpretation of these codes of ethics is perhaps the biggest challenge of this project and, considering their multi-jurisdictional nature, the synthesis and teleological interpretations are principal, while the purposive and mischief approaches are auxiliary (Chirita 2014; MacGregor Pelikánová 2018). Therefore, the quantitative content analysis based on automatic word scanning is rather auxiliary and merely indicates the number of appearances of SDG keywords as highlighted in Table 1. In contrast, the qualitative content analysis via a simplified Delphi method (MacGregor Pelikánová 2019a) entailing a manual scoring $(+)$ or $(++)$ or $(+++)$ of the depth of engagement with SDGs by a panel of three experts, is principal. This panel consists of three experts on corporate ethics and CSR matters including reporting (JK, LM, and RKM), who have carefully studied all 30 codes of ethics while following a universal set of guidelines and simple questionnaires prepared by the authors. All three experts are masters in English, have college degrees, experience with codes, at least 20 years of executive job experience, and a strong law and/or economic background. Two of them are women and one is a man. Thus, their scoring met the expertise expectations, and this especially after cleaning scoring discrepancies in the first and second rounds. Pursuant to these guidelines and questionnaires, each of these three experts scored the reflection of SDGs in codes of ethics while using $(0)$ or $(+)$ or $(++)$ or $(+++)$ : no indices about SDG $(0)$, general or weak $(+)$, advanced $(++)$, and genuinely deep and measurable $(+++)$. Further, these three experts identified SDG actionability (proclamation v. quasi-enforceable statement) and the nature of the commitment (merely negative-passive, also known as avoiding harm vs. positive-active ethical duty, also known as doing good).

The first question is a typical "how" question and deals with the manner of the projection of 17 SDGs in the codes of ethics of these 20+10 large European businesses. Specifically, it focusses on the presence or absence of expressed or implied mentions of SDGs and on their understanding in the dynamics of natural and positivist law, i.e., whether such a mentioned SDG is moved from the moral duty to a semi-enforceable duty. Naturally, the pivotal element is the comparative content exploration of these codes in the mentioned perspectives, i.e., the intrinsic as well as extrinsic descriptive analysis while using content quantitative and qualitative methods, as shown in Tables 5 and 6.

The second question is a typical "why" question and attempts to discover possible reasons for the imperfect and/or weak projection of SDGs in codes of ethics. The second question organically builds upon the first question and its finding by engaging deeply in codes of ethics and by using, along with the mentioned complementary dual content analysis, Socratic questioning as well (Areeda 1996). Such a holistic and comparative processing via critical meta-analysis is trend and reason indicative (Cerchia and Piccolo 2019). In addition, it is suitable to address various industries' particularities (Arminen et al. 2018) and the ephemeral intellectual property via research and development (R\&D) leading to innovations (Dima et al. 2018; Zaušková and Rezníčková 2020; Trettin et al. 2019; Udell et al. 2019; Zhuravleva et al. 2019; Kliestik et al. 2020; Peters et al. 2020). Naturally, the main focus regarding the second question has rather qualitative and heuristic, than quantitative and conventionally, statistical features. It critically works on the intensity of the SDG commitment, dialectic discrepancies between the frequency and depth of the SDG commitment, on compliance likelihood (Kolk and 
Tulder 2005), and SDG actionability (internal vs. external) and embracement (negative-passive vs. positive-active) (Van Zanten and Tulder 2018).

However, the pre-requirement for the addressing of these two challenging and pioneering questions is not only an appropriate literature review and methodology. Indeed, the rather empirical exploration, interpretation, and scoring of codes of ethics needs to be preceded by a rather theoretic feasibility assessment, i.e., a theoretical study of the presence or absence of codes of ethics to overlap with SDGs and so, consequently, the potential of SDGs to be effectively and efficiently projected in codes of ethics.

\section{Codes of Ethics and Their Potential for an Overlap with SDG-Theory}

As mentioned above, the rightness of an action is determined by the character of the principle that a person chooses to act upon (Kant [1785] 2011) in a real-life context (Taylor 2018). If such a principle is about all-encompassing economic, social, and environmental responsibility towards the society (Olšanová et al. 2018), then the right and ultimately effective behavior should be strongly overlapping with sustainability and CSR. This leads to a myriad of responsibilities (Sroka and Szántó 2018), such as economic and ethical, while only a few of them attain law enforceability, such as legal liability. In such a context, came into the picture codes of ethics, which allow businesses to express themselves in how far they want and are ready to go with "right" behavior, which is not mandatory (Sroka and Lőrinczy 2015). They bring a moral compass that must be used to measure reality (Weber and Wasieleski 2013) along with a social obligation to go above and beyond law (legal) duties as expected by (at least some) stakeholders (Hoover and Pepper 2015; Adelstein and Clegg 2016).

Therefore, it is possible to stop here and plainly state that, if codes of ethics are about "right things to be done for the society even if not mandatory", and SDGs are about "right goals for the society to be achieved even if not mandatory", then prima facie there is a clear conceptual overlap between codes of ethics and SDGs. Nevertheless, such a statement might be perceived as impulsive and intuitive, and so, in order to establish its academic and logic robustness, each and every SDG needs to be put in the perspective of codes of ethics and their universal six moral values-credibility, respect, responsibility, honesty, care, and citizenship (McDonald 2009)—and the following four pivotal principles:

- The principle of personality to enhance autonomy and authenticity of the individuals;

- The principle of solidarity which requires being and working together;

- The principle of subsidiarity against unreasonably distant decision-making leadership;

- The principle of the environmental protection to respect the world.

Each code of ethics is a particular, more or less realistic, original declaration reflecting a unique business wanting to address especially certain stakeholders, i.e., focusses differently on this quartet of principles (Zolingen and Honders 2010; Fatemi et al. 2018) based on stakeholders' priorities (Erwin 2011; Ikonen et al. 2017), moral maturity of each level of management (Haessler 2020; Messikomer and Circa 2010; Vogel 2010; Cerchia and Piccolo 2019), and industry particularities, etc. (Perez-Batres et al. 2012).

Nevertheless, even if codes of ethics can be very different, they virtually always have a meta-ethical dimension and, although they are not legally binding, their violation may lead to negative consequences, such as a lack of personal appraisal or negative publicity or even a rejection by stakeholders (Kaptein 2011; Oladinrin and Ho 2016). Consequently, codes have a genuine potential to provide self-regulation, which may reduce the need of having external legislative regulations of businesses (Babri et al. 2019). Table 4 demonstrates a clear overlap for each SDG with this quartet of pivotal principles for codes of ethics.

Therefore, it can be considered as established that there is an obvious potential for the projection of SDGs in codes of ethics, and this is fully in compliance with the quartet of pivotal principles for codes of ethics. Well, the theory provides a clearly affirmative answer to the first question-yes, SDGs are to be projected in codes of ethics. However, what does it say in the real world? 
Table 4. Theory—the overlap of 17 SDGs with 4 pivotal principles of codes of ethics.

\begin{tabular}{|c|c|c|c|c|}
\hline SDG & $\begin{array}{l}\text { Autonomy } \\
\text { Individuals }\end{array}$ & $\begin{array}{l}\text { Solidarity } \\
\text { Together }\end{array}$ & Subsidiarity & $\begin{array}{c}\text { Environment } \\
\text { Protection }\end{array}$ \\
\hline 1. End poverty ... everywhere & Yes & Yes & Yes & No \\
\hline 2. End hunger ... sustainable agriculture & Yes & Yes & Yes & Yes \\
\hline 3. Ensure healthy lives ... well-being & Yes & Yes & Yes & Yes \\
\hline 4. Ensure inclusive equitable education & Yes & Yes & No & No \\
\hline 5. Achieve gender equality & Yes & Yes & No & No \\
\hline 6. Availability ... sustainable water & Yes & Yes & No & Yes \\
\hline 7. Access to affordable sustainable energy & Yes & Yes & No & Yes \\
\hline 8. Inclusive sustainable economic growth & Yes & Yes & No & Yes \\
\hline 9. Sustainable industrialization innovation & Yes & No & No & Yes \\
\hline 10. Reduce inequality ... among countries & Yes & Yes & No & No \\
\hline 11. Sustainable human settlements safe & Yes & Yes & No & No \\
\hline 12. Sustainable consumption production & No & Yes & Yes & Yes \\
\hline 13. Action to combat climate change & No & No & Yes & Yes \\
\hline 14. Sustainably use the oceans, seas, ... & No & Yes & Yes & Yes \\
\hline 15. Sustainable use of terrestrial ecosystem & No & No & Yes & Yes \\
\hline 16. Peace, access to justice for all & Yes & Yes & Yes & No \\
\hline 17. Global Partnership for Sustain. Dev. & No & Yes & Yes & Yes \\
\hline
\end{tabular}

Source: Prepared by the authors based on the codes of ethics of studied businesses.

\section{Codes of Ethics and Their Overlap with SDG-Reality}

The mentioned panel of experts has studied, analyzed, and scored, via the Delphi-method, the codes of ethics of the selected businesses, while indicating the frequency/number of keywords indicating a particular SDG, scoring the depth of engagement, and the actionability and nature of such a commitment. Table 5 summarizes the results for the first group, i.e., 20 large Czech businesses.

Table 5. Case study—first group-included SDGs, their frequency (\#) and score (+), and their actionability (declaratory vs. compulsory) and nature (passive vs. active).

\begin{tabular}{|c|c|c|c|}
\hline & Business & SDG (\#/+) & Commitment (dc/pa) \\
\hline 1. & Škoda Auto, a.s. & SDG3(15/+) SDG4(1/+) SDG12(4/++) & Declaratory active \\
\hline 2. & ČEZ, a.s. & $\begin{array}{c}\text { SDG }(1 /+) \text { SDG } 4(1 /+) \\
\text { SDG5 }(1+)\end{array}$ & Declaratory active \\
\hline 3. & Agrofert, a.s. & $\begin{array}{l}\text { SDG3 }(4 /+) \text { SDG }(1 /+) \\
\text { SDG5 }(1 /+) \text { SDG9 }(1 /+)\end{array}$ & Declaratory active \\
\hline 4. & $\begin{array}{c}\text { Energetický a Průmyslový Holding, } \\
\text { a.s. }\end{array}$ & $\begin{array}{c}\text { SDG4 }(12 /++) \text { SDG7 }(196 /++) \\
\text { SDG8(21/++) SDG9 }(5 /++) \\
\text { SDGS12(35/++) DG13(33/++) }\end{array}$ & Compulsory active \\
\hline 5. & UNIPETROL, a.s. & $\begin{array}{l}\text { SDG3(10/++) SDG4(1/+) SDG5(2/+) } \\
\text { SDG8(1/+) SDG12(1/+) SDG 17(2/+) }\end{array}$ & Compulsory active \\
\hline 6. & RWE Supply \& Trading CZ a.s. & $\begin{array}{l}\text { SDG3(3/+) SDG4(2/+) SDG9(1/+) } \\
\text { SDG12(1/+) }\end{array}$ & Declaratory active \\
\hline 7. & Foxconn Technology CZ, s.r.o. & $\operatorname{SDG} 3(3 /+)$ & Declaratory active \\
\hline 8. & Continental Automotive CZ s.r.o. & $\begin{array}{l}\text { SDG5(4/+) SDG6(1/+) SDG7(1/+) } \\
\text { SDG9(3/+) SDG13(3/++) }\end{array}$ & Declaratory active \\
\hline 9. & Kaufland Česká Republika, v.o.s. & $\begin{array}{l}\text { SDG3(1/+) } \operatorname{SDG5}(2 /+) \text { SDG6(1/+) } \\
\text { SDG14(1/+) }\end{array}$ & Declaratory passive \\
\hline 10. & Albert Česká repulika, s.r.o. (Ahold) & SDG3 $(3 /++)$ SDG5 $(1 /++)$ & Declaratory active \\
\hline 11. & ČEPRO, a.s. & $\begin{array}{c}\text { SDG3(1/++) SDG5 }(1 /++) \text { SDG7 }(1 /++) \\
\text { SDG9(1/++) SDG12(1/++) SDG16(1/++) }\end{array}$ & Compulsory active \\
\hline 12. & Finitrading a.s. (Třinecké želez.) & $\begin{array}{c}\operatorname{SDG} 3(2 /++) \operatorname{SDG} 13(1 /+) \\
\operatorname{SDG}(1 /+) \mathrm{SDG} 3(14 /++) \operatorname{SDG} 4(2 /+)\end{array}$ & Declaratory passive \\
\hline 13. & MOL Česká republika, s.r.o. & $\begin{array}{l}\text { SDG5(2/+) SDG6(1/+) SDG8(1/+) } \\
\text { SDG9(5/++) SDG16(1/+) }\end{array}$ & Compulsory active \\
\hline 14. & E.ON Česká republika, s.r.o. & $\begin{array}{l}\text { SDG3(11/++) SDG4 } 4(1 /++) \text { SDG5(1/+) } \\
\text { SDG7(4/+) SDG } 9(2 /+)\end{array}$ & Declaratory active \\
\hline 15 & O2 Czech Republic a.s. & SDG3(1/+) SDG9(3/+) SDG17(1/+) & Declaratory passive \\
\hline 16. & České Dráhy, a.s. & $\operatorname{SDG} 5(2 /+) \operatorname{SDG} 9(2 /+)$ & Declaratory passive \\
\hline 17. & Metrostav a.s. & $\begin{array}{c}\text { SDG5(1/+) SDG9(1/+) } \\
\text { SDG3(3/+) SDG4(2/+) SDG5(3/+) }\end{array}$ & Declaratory passive \\
\hline 18. & VEOLIA ČESKÁ REPUBLIKA, a.s. & $\begin{array}{l}\text { SDG6(2/+) SDG7(2/+) SDG9 }(5 /++) \\
\text { SDG13(1/+) SDG17(3/+) }\end{array}$ & Declaratory active \\
\hline 19. & T-Mobile Czech Republic a.s. & SDG3(3/+) SDG6(2/+) SDG7(1/+) & Declaratory passive \\
\hline 20. & Skanska, a.s. & $\operatorname{SDG} 3(8 /++) \operatorname{SDG} 9(2 /+) \operatorname{SDG} 17(1 /+)$ & Declaratory active \\
\hline
\end{tabular}


The message conveyed by the codes of conduct of these largest Czech businesses could be summarized as: codes of ethics are heterogeneous, more declaratory then enforceable, and slightly more oriented towards active action than passive omission. The focal points are inside stakeholders, predominantly employees, rather than outside stakeholders, such as the community. The most popular SDGs are SDGs linked to the business operations per se and employees, i.e., SDG3, SDG5 and SDG9. Paradoxically, although there is a clear drive for innovation (SDG9), it is not appropriately matched by the necessary education (SDG4). Global topics, such as climate change (SDG13) are underplayed, some of them are even totally avoided (SDG14, SDG15). The drive for the rule of law (SDG16) and various forms of partnership (SDG17) is weak. Surprisingly, the notion of justice (SDG16) is missing. These rather grim results call for double checking by the "mother" and "sister" businesses of these Czech large businesses, see Table 6.

Table 6. Case study—second group. Case study included SDGs, their frequency (\#) and score (+), and their actionability (declaratory vs. compulsory) and nature (passive vs. active).

\begin{tabular}{|c|c|c|c|}
\hline & European Business & SDGs (\#/+) & Commitment (dc/pa) \\
\hline 21. & Ahold Delhaize & $\begin{array}{c}\text { SDG3(3/++) SDG5(2/++) } \\
\text { SDG9(1/+) SDG12(1/+) } \\
\text { SDG3(6/++) SDG5(4/+) }\end{array}$ & Compulsory active \\
\hline 22. & Continental AG & $\begin{array}{c}\text { SDG7(1/+) SDG8(1/+) } \\
\text { SDG9(3/++) SDG12(8/++) } \\
\text { SDG13(3/++) }\end{array}$ & Compulsory active \\
\hline 23. & Deutsche Telekom AG & $\begin{array}{l}\text { SDG4(1/+) SDG17(1/+) } \\
\text { SDG1(1/+) SDG4(14/++) }\end{array}$ & Declaratory passive \\
\hline 24. & Mol Group & $\begin{array}{c}\text { SDG4 }(2 /+) \text { SDG5 }(11 /++) \\
\text { SDG9(5/+) SDG16(1/+) } \\
\text { SDG17(2/+) }\end{array}$ & Compulsory active \\
\hline 25. & $\begin{array}{c}\text { Orlen Polski Koncern } \\
\text { Naftowy SA }\end{array}$ & $\begin{array}{c}\text { SDG3(9/++) SDG5(1/+) } \\
\text { SDG5(1/+) SDG8 }(2 /+) \\
\text { SDG9(2/+) SDG17(4/+) } \\
\text { SDG5(1/+) SDG7(1/+) }\end{array}$ & Declaratory active \\
\hline 26. & RWE Group & $\begin{array}{l}\text { SDG9(1/+) SDG12(7/++) } \\
\text { SDG13(3/+) SDG16(1/+) } \\
\text { SDG3(26/++) SDG4(5/++) }\end{array}$ & Declaratory active \\
\hline 27. & Skanska Group HQ & $\begin{array}{l}\text { SDG5(10/++) SDG6(3/++) } \\
\text { SDG7(1/+) SDG9(3/+) } \\
\text { SDG13(6/++) SDG17(1/++) }\end{array}$ & Compulsory active \\
\hline 28. & Telefónica & $\begin{array}{c}\text { SDG3(3/+) SDG4(1/+) } \\
\text { SDG5(2/+) SDG7(1/+) } \\
\text { SDG9(1/+) SDG12(1/+) } \\
\text { SDG3(9/++) SDG4(2/+) }\end{array}$ & Declaratory passive \\
\hline 29. & Veolia & $\begin{array}{c}\text { SDG5(2/+) SDG9(4/+) } \\
\text { SDG12(4/+) SDG13(1/+) } \\
\text { SDG17(3/+) }\end{array}$ & Declaratory active \\
\hline 30. & Volkswagen Group & $\begin{array}{c}\text { SDG3(11/+) SDG4 }(1 /+) \\
\text { SDG5(5/+) SDG7(1/+) } \\
\text { SDG9 }(1 /+) \text { SDG12(1/+) } \\
\text { SDG17(1/+) }\end{array}$ & Declaratory active \\
\hline
\end{tabular}

Prepared by the authors based on Internet domains of businesses.

The message conveyed by codes of conduct of these large European businesses could be summarized as: codes of ethics are heterogeneous, more declaratory then enforceable, and oriented more towards active action than passive omission. The focal points are not clearly facing inside stakeholders. The most popular SDGs are SDGs linked to the business philosophy, i.e., SDG3, SDG5, SDG9, SDG13, and SDG17. Although there is a clear drive for innovations (SDG9), it is not properly matched by the necessary education (SDG4). The drive for the rule of law (SDG16) and various forms of partnership (SDG17) is noticeable. Surprisingly, the notion of justice (SDG16) is often missing. These results are just a little bit better than those regarding their Czech "daughter" and "sister" businesses. 


\section{Results and Discussion}

Pursuant to Milton Friedman, policies and programs are to be judged not by their intentions, but rather by their results (Bali Swain and Yang-Wallentin 2019). The performed case study has a potential to shield the light and deal with the semi-impact of SDGs on private business policies. At the same time, it must be realistically admitted, that the performed case study is inherently rather indicative than conclusive and should be appreciated as a pioneering attempt to study the (lack of) projection of SDGs in codes of ethics and the underlying reasons and causes. It needs to be emphasized that the case study involved a rather homogenous and at the same time multi-sectorial sample increasing the robustness of generated preliminary propositions. To put it differently, the sample entailed top candidates for a smooth projection of SDGs in their codes and any failures and shortcomings by these large and cross-border businesses is highly relevant and likely to occur as well by smaller and less international businesses. Indeed, despite its rather small size, the performed case study with the support of the provided conceptual and literature background offers a set of highly relevant suggestions deserving comparative and Socratic glossing.

Firstly, although codes of ethics are heterogeneous-regarding their content as well as their form-they are inclined more towards being declaratory rather than enforceable and to be rather more active than passive. Compared to findings in recent prior studies, analyses, and publications (Ikonen et al. 2017; Kaptein 2011; Schaltegger et al. 2018), this is slightly disappointing (Adelstein and Clegg 2016), but not completely surprising (Arora et al. 2020; Perez-Batres et al. 2012). European businesses appear to be slightly readier to go for mandatory and active features than Czech businesses. Inherently, this calls for further studies and explanations, especially regarding underlying roots slowing large Czech businesses, members of international holding groups, in their drive for an enforceable and active commitment.

Secondly, Czech codes of ethics are pre-occupied with employees and the daily business operations in the narrow sense, while European codes of ethics appear to be more oriented towards going for higher and more abstract targets and take more into consideration the global dimension, such as the perception of SDG3 and SDG5. This confirms preliminary suggestions published about particularities of the Czech market and low unemployment, especially extremely low unemployment with respect to regions and professions involving large and luxury fashion businesses (MacGregor et al. 2020a, 2020b; MacGregor Pelikánová 2019a).

Thirdly, closer patterns can be observed within the same holding (group) of companies and naturally the mother business leads the van. However, more surprisingly, there are definitely national (or individual) particularities and there is definitely not a unification across these holdings (groups):

- Ahold-Albert: The Czech business is very much reduced to the local employees' approach.

- Continental-Continental: Czech business goes rather for the declaratory style.

- Deutsche Telekom-T-Mobile: Both businesses are not genuinely engaged.

- MOL-MOL: Both businesses work on a larger perspective and SDGs reflecting codes of ethics.

- Orlen-Unipetrol: Both businesses work on a larger perspective and SDGs reflecting codes of ethics.

- RWE-RWE: Similar codes of ethics.

- Skanska-Skanska: The Czech business is way behind its European mother business.

- Telefónica-O2: A low commitment, and this is even lower for the Czech business.

- Veolia-Veolia: Similar codes of ethics.

- Volkswagen-Škoda: The Czech Škoda business is just weakly engaged and its German mother is only slightly better.

Fourthly, across all these 30 codes of ethics, three groups of SDGs can be observed, based on the criterion of their "popularity" for codes of ethics-always projected SDGs (e.g., SDG3), sometimes projected SDGs (e.g., SDG 12), and never projected SDGs (e.g., SDG11). Table 7, below, reveals more information in this respect. 
Table 7. Reality of SDGs' popularity and projection.

\begin{tabular}{|c|c|c|}
\hline SDG & Projection & Comments \\
\hline 1. End poverty ... everywhere & Weakly and generally mentioned & Seldom used \\
\hline 2. End hunger $\ldots$ sustainable agriculture & 0 & Totally missing \\
\hline 4. Ensure inclusive equitable education & Focus on education for employees & Self-centered perception (except EPH) \\
\hline 5. Achieve gender equality & Focus on employee race discrimination & $\begin{array}{l}\text { Very narrow perception } \\
\text { (except MOL, EON, Skanska) }\end{array}$ \\
\hline 7. Access to affordable sustainable energy & Only a general mention & Missed by the majority \\
\hline 8. Inclusive sustainable economic growth & Rather a general mention & Rather rare \\
\hline 9. Sustainable industrialization innovation & Innovation covered by the majority, but not all & Rather popular, but very general \\
\hline 10. Reduce inequality $\ldots$ among countries & $\begin{array}{c}\text { Indirectly along with employee race } \\
\text { discrimination }\end{array}$ & Very narrow perception \\
\hline 11. Sustainable human settlements safe & 0 & Totally missing \\
\hline 16. Peace, access to justice for all & Weakly and generally mentioned & Missing "justice" (except for Rwe) \\
\hline 17. Global Partnership for Sustainable Dev. & $\begin{array}{l}\text { At least some partnership reflected by only a } \\
\text { few businesses }\end{array}$ & Point of difference \\
\hline
\end{tabular}

Source: Prepared by the authors based on the codes of ethics of the studied businesses.

Fifthly, the case study brought a set of unexpected propositions. Businesses want the innovation (SDG9), but they often ignore the education (SDG4). This is inconsistent with well-established interrelation (MacGregor Pelikánová 2019c) and a long line of studies (Dima et al. 2018; Whitehouse 2010). Similarly, businesses include environmental notes in their codes of ethics, but often avoid the burning issue of climate change. Even more paradoxically, the large majority of codes of ethics pass on the peace-justice-rule of law (SDG16) and even skip the notion "justice".

Exactly these paradoxes and unexpected revelations could arguably be the key for the understanding and explanation of the imperfect projection of the SDGs in both Czech and European codes of ethics. The literature review pointed out that the blame goes typically to the unrealistic UN and to the inherent difficulty in measuring progress in this field. However, it should be added that the lack of awareness and a total misunderstanding of the conceptual foundations apply to codes of ethics, or better to say to their authors. Boldly, the authors of codes of ethics often do not know very much about SDGs, and they also know very little about the transposition and adjustment of moral and ethical values in business strategies. These authors have a fairly weak understanding of the geometric and arithmetic justice by Socrates and do not dare to lift their eyes from the daily business operations and truly work with the visions and missions of the given business to go for higher aspirations. Perhaps SDGs are not properly set by the UN, but, for sure, the large majority of codes of ethics are not really true codes of ethics as well defined. Maybe this is a story of being "lost in translation", where actually SDGs set from above could be an impulse for the bottom, to make the bottom realize what is the true meaning and importance of sustainability and CSR.

\section{Conclusions}

A case study of internal declaratory documents about sustainability and other ethical commitments, codes of ethics, is highly relevant and indicative due to the selected sample, even if not conclusive due to its size. Firstly, it reveals the heterogeneity of codes of ethics as well as their common drive for declaratory active features. Certain SDGs are warmly welcomed and projected by them, while other SDGs are only half-heartedly mentioned and finally there are SDGs totally ignored by codes of ethics. Secondly, European codes of ethics are typically more globally and community oriented than Czech codes of ethics, which are almost paralyzed with the "employee" issue. Thirdly, often, but not always, businesses from the same group have codes of ethics demonstrating similarities. Fourthly, a large difference of popularity between various SDGs can be observed. Fifthly, codes demonstrate a myriad of consistencies, see SDG4 vs. SDG9, SDG13 and SDG16. Indeed, almost all codes pass on the concept 
of justice and this is against all logic and expectations. This leads to the preliminary proposition about the immaturity of the authors of codes of ethics, about national and cultural particularities, and about the positive potential of SDGs to, despite their massive criticism, become an enhancement awareness point and compass. Certainly, these main five findings, along with the indicated rather pioneering propositions, call for further studies in order to confirm them, to understand their reasons and roots, and to generate propositions about the potential for improvement.

In sum, the main five findings point out to deep conceptual misunderstandings and shortcomings by businesses, which do not properly work with their codes of ethics and which could benefit from, at least partially, the SDGs' guidance. These rather pioneering propositions are not conclusive due to the inherent and inevitable limitations of the performed case study and needs to be verified over time (longitudinally), while expanding the pool of studied codes of ethics. Further, it would be highly interesting to get inside information about the authors of these codes of ethics and the whole process of their drafting and approving the codes of ethics. Empirical interviews, as well as deeper studies of codes of ethics, could be extremely enlightening. Finally, the ultimate judge should be heard from-external stakeholders. Hence, case studies working with consumers and investors and their attitudes to codes of ethics and SDGs and the ongoing projection are highly desirable.

Author Contributions: Both authors contributed equally to this work. Conceptualization, A.P.B. and R.M.P.; methodology, A.P.B. and R.M.P.; formal analysis, A.P.B. and R.M.P.; case studies, A.P.B. and R.M.P.; resources, A.P.B. and R.M.P.; data curation, A.P.B. and R.M.P.; writing-original draft preparation, A.P.B. and R.M.P.; writing-review and editing, A.P.B. and R.M.P. All authors have read and agreed to the published version of the manuscript.

Funding: This research received no external funding.

Conflicts of Interest: The authors declare no conflict of interest.

\section{References}

Adelstein, Jennifer, and Stewart Clegg. 2016. Code of Ethics: A Stratified Vehicle for Compliance. Journal of Business Ethics 138: 53-66. [CrossRef]

Adshead, Daniel, Scott Thacker, Lena I. Fuldauer, and Jim W. Hall. 2019. Delivering on the Sustainable Development Goals through long-term infrastructure planning. Global Environmental Change 59: 101975. [CrossRef]

Ainsworth-Rowen, Emily. 2019. Networked, Smart, and Responsive Devices in Sustainable Internet-of-Thingsbased Manufacturing Systems: Industrial Value Creation. Cognitive Decision-Making Algorithms, and Operational Performance Improvement Economics, Management, and Financial Markets 14: 9-15.

Androniceanu, Armenia. 2019. The Social Sustainability of Smart Cities: Urban Technological Innovation, Big Data Management, and the Cognitive Internet of Things. Geopolitics, History, and International Relations 11: 110-15.

Areeda, Philip E. 1996. The Socratic Method. Harvard Law Review 109: 911-22.

Arminen, Heli, Kaisu Puumalainen, Satu Pätäri, and Katharina Fellnhofer. 2018. Corporate social performance: Inter-industry and international differences. Journal of Cleaner Production 177: 426-37. [CrossRef]

Arora, Bimal, Arno Kourula, and Robert Phillips. 2020. Emerging Paradigms of Corporate Social Responsibility, Regulation, and Governance: Introduction to the Thematic Symposium. Journal of Business Ethics 162: 265-68. [CrossRef]

Babri, Maira, Bruce Davidson, and Sven Helin. 2019. An Updated Inquiry into the Study of Corporate Codes of Ethics: 2005-2016. Journal of Business Ethics. [CrossRef]

Bali Swain, Ranjula. 2018. A critical analysis of the sustainable development goals. In Handbook of Sustainability Science and Research. Edited by W. Leal Filho. Berlin/Heidelberg/New York: Springer International Publishing, pp. 341-55.

Bali Swain, Ranjula, and Fan Yang-Wallentin. 2019. Achieving sustainable development goals: Predicaments and strategies. International Journal of Sustainable Development, and World Ecology 27: 96-106. [CrossRef]

Belas, Jaroslav, Khurram Ajaz Khan, Josef Marousek, and Zoltan Rozsa. 2020. Perceptions of the importance of business ethics in SMEs: A comparative study of Czech and Slovak entrepreneurs. Ethics E Bioethics 10: $96-106$. 
Cerchia, Rosella E., and Katherine Piccolo. 2019. The Ethical Consumer and Codes of Ethics in the Fashion Industry. Laws 8: 23. [CrossRef]

Chirita, Anca D. 2014. A Legal-Historical Review of the EU Competition Rules. International E Comparative Law Quarterly 63: 281-316.

Clark, Cynthia E., Erika Steckler, and Sue Newell. 2016. Managing contradiction: Stockholder and Stakeholder views of the firm as paradoxical opportunity. Business and Society Review 121: 123-59. [CrossRef]

Czyżewski, Bazyli, Jan Polcyn, and Anna Hnatyszin-Dzikowska. 2016. Concept for Measuring the Efficiency of Public Goods Provision Based on the Education Sector in Poland. Ekonomický Časopis 64: 973-93.

Desai, Renu, and Robin Roberts. 2013. Deficiencies in the code of conduct: The AICPA rhetoric surrounding the tax return preparation outstanding disclosure rules. Journal of Business Ethics 114: 457-71. [CrossRef]

Di Maddaloni, Francesco, and Roya Derakshan. 2019. A Leap from Negative to Positive Bond. A Step towards Project Sustainability. Administrative Sciences 9: 41. [CrossRef]

Dima, Alina M., Liviu Begu, Maria D. Vasilescu, and Maria A. Maassen. 2018. The Relationship between the Knowledge Economy and Global Competitivness in the European Union. Sustainability 10: 1706. [CrossRef]

Džupina, Milsn, and Zuzana Džupinova. 2019. Dimensions of CSRE in Online Communication of Pharmaceutical Companies: A Comparative Study. International Journal of Entrepreneurial Knowledge 6: 41-52. [CrossRef]

Easterly, William. 2015. The trouble with the sustainable development goals. Current History 114: 322-24. [CrossRef]

Erwin, Patrick M. 2011. Corporate Codes of Conduct: The Effects of Code Content and Quality on Ethical Performance. Journal of Business Ethics 99: 535-48. [CrossRef]

Fatemi, Darius, John Hasseldine, and Peggy Hite. 2018. The Influence of Ethical Codes of Conduct on Professionalism in Tax Practice. Journal of Business Ethics 164: 133-49. [CrossRef]

Galli, Alessandro, Gordana Durovic, Laurel Hanscom, and Jelena Kneževic. 2018. Think globally, act locally: Implementing the sustainable development goals in Montenegro. Environmental Science E Policy 84: 159-69.

Girard, Carine, and André Sobczak. 2012. Towards a Model of Corporate and Social Stakeholder Engagement: Analyzing the Relations Between a French Mutual Bank and Its Members. Journal of Business Ethics 107: 215-25. [CrossRef]

Glass, Gene. 1976. Primary, secondary, and meta-analysis of research. Educational Researcher 5: 3-8. [CrossRef]

Haessler, Phillip. 2020. Strategic Decisions between Short-Term Profit and Sustainability. Administrative Sciences 10: 63. [CrossRef]

Harymawan, Iman, Mohammad Nasih, Atila Salsabilla, and Fajar Kristanto Gautama Putra. 2020. External assurance on sustainability report disclosure and firm value: Evidence from Indonesia and Malaysia. Entrepreneurship and Sustainability Issues 7: 1500-12. [CrossRef]

Hayhoe, Terry, Ivana Podhorska, Anna Siekelova, and Vojtech Stehel. 2019. Sustainable Manufacturing in Industry 4.0: Cross-Sector Networks of Multiple Supply Chains, Cyber-Physical Production Systems, and AI-driven Decision-Making. Journal of Self-Governance and Management Economics 7: 31-36.

Heckman, James J. 2005a. The Scientific Model of Causality. Sociological Methodology 35: 1-98. [CrossRef]

Heckman, James J. 2005b. Rejoinder: Response to Sobel. Sociological Methodology 35: 135-62. [CrossRef]

Hoover, Kristine, and Molly Pepper. 2015. How did they say that? Ethics statements and normative frameworks at best companies to work for. Journal of Business Ethics 131: 605-17. [CrossRef]

Horská, Elena, Serhiy Moroz, Zuzana Poláková, Ĺudmila Nagyová, and Ihor Paska. 2019. Evaluation of interaction between chosen indicators of development of regions in Ukraine. Equilibrium. Quarterly Journal of Economics and Economic Policy 14: 341-57. [CrossRef]

Idowu, Samuel O., René Schmidpeter, and Liangrong Zu. 2019. The Future of the UN Sustainable Development Goals_Business Perspectives for Global Development in 2030. Berlin/Heidelberg/New York: Springer.

Ikonen, Pasi, Vilma Luoma-aho, and Shannon A. Bowen. 2017. Transparency for Sponsored Content: Analysing Codes of Ethics in Public Relations, Marketing, Advertising and Journalism. International Journal of Strategic Communication 11: 165-78. [CrossRef]

Ionescu, Luminița. 2019. Towards a Sustainable and Inclusive Low-Carbon Economy: Why Carbon Taxes, and Not Schemes of Emission Trading, Are a Cost-Effective Economic Instrument to Curb Greenhouse Gas Emissions. Journal of Self-Governance and Management Economics 7: 35-41.

Kant, Immanuel. 2011. Groundwork of the Metaphysics of Morals: A German-English Edition. Translated and Edited by Mary Gregor and Jens Timmermann. Cambridge: Cambridge University Press. First published in 1785. 
Kaptein, Muel. 2011. Toward effective codes: Testing the relationship with unethical behavior. Journal of Business Ethics 99: 233-51. [CrossRef]

Khan, Khurram Ajaz, Gentjan Çera, and Vaclav Nétek. 2019. Perception of the Selected Business Environment Aspects by Service Firms. Journal of Tourism and Services 10: 111-27. [CrossRef]

Kisel'áková, Dana, Beáta Šofranková, Erika Onuferová, and Veronika Čabinová. 2019. The evaluation of competitive position of EU-28 economies with using global multi-criteria indices. Equilibrium. Quarterly Journal of Economics and Economic Policy 14: 441-62. [CrossRef]

Kliestik, Tomáš, Elvira Nica, Hussam Musa, Miloš Poliak, and Eleodor Alin Mihai. 2020. Networked, smart, and responsive devices in Industry 4.0 manufacturing systems. Economics, Management, and Financial Markets 15: 23-29.

Kolk, Ans, and Rob van Tulder. 2005. Setting new global rules? TNCs and codes of conduct. Transnational Corporations 14: 1-27.

Kot, Sebastian. 2018. Sustainable supply chain management in small and medium enterprises. Sustainability 10: 1143. [CrossRef]

Kot, Sebastian, Ioana Raluca Goldbach, and Beata Ślusarczyk. 2018. Supply chain management in SMES-Polish and Romanian approach. Economics and Sociology 11: 142-56. [CrossRef]

Krajnakova, Emilia, Valentinas Navickas, and Rima Kontanutiene. 2018. Effects of macroeconomic business environment on the development of corporate responsibility in Baltic Countries and Slovakia. Oeconomia Copernicana 9: 477-92. [CrossRef]

Kuckartz, Udo. 2014. Qualitative Text Analysis-A Guide to Methods, Practice and Using Software, 1st ed. London: Sage Publications Ltd.

Lafferty, Clive. 2019. Sustainable Industry 4.0: Product Decision-Making Information Systems, Data-driven Innovation, and Smart Industrial Value Creation. Journal of Self-Governance and Management Economics 7: 19-24.

Lere, John C., and Bruce R. Gaumnitz. 2003. The Impact of Codes of Ethics on Decision Making: Some Insights from Information Economics. Journal of Business Ethics 48: 365-79. [CrossRef]

Linnhoff, Stefan, Hannah Russell, Katherine T. Smith, and Murphy Smith. 2014. A Descriptive Analysis of Ethics Codes, CSR, and Efforts to Combat Human Trafficking. International Journal of Corporate Governance 5: 156-77. [CrossRef]

MacGregor, Robert K., Włodzimierz Sroka, and Radka MacGregor Pelikánová. 2020a. A Comparative Study of the Low Managers Attitude to Marketing and Innovations in Luxury Fashion Industry: Pro-Or Anti-CSR? Polish Journal of Management Studies 21: 240-55. [CrossRef]

MacGregor, Robert K., Włodzimierz Sroka, and Radka MacGregor Pelikánová. 2020b. The CSR Perception of Front-line Employees of Luxury Fashion Businesses: Fun or Free for Sustainability? Organizacija 53: 198-211. [CrossRef]

MacGregor Pelikánová, Radka. 2017a. European Myriad of Approaches to Parasitic Commercial Practices. Oeconomia Copernicana 8: 167-80. [CrossRef]

MacGregor Pelikánová, Radka. 2017b. Constantine's Christianity for the (Dis)integrated EU—Déjà vu of Constantine‘s Roman governance reflecting of the mistrial of Jesus for EU? Dialogo 4: 81-98.

MacGregor Pelikánová, Radka. 2018. The nebulous effectiveness, efficiency and fairness of the European e-Justice Portal vis-à-vis Corporate Social Responsibility. Progress in Economic Sciences 5: 127-41.

MacGregor Pelikánová, Radka. 2019a. Corporate Social Responsibility Information in Annual Reports in the EU-Czech Case Study. Sustainability 11: 237. [CrossRef]

MacGregor Pelikánová, Radka. 2019b. Harmonization of the protection against misleading commercial practices: Ongoing divergences in Central European countries. Oeconomia Copernicana 10: 239-52. [CrossRef]

MacGregor Pelikánová, Radka. 2019c. R\&D expenditure and innovation in the EU and selected member states. Journal of Entrepreneurship, Management and Innovation 15: 13-33.

MacGregor Pelikánová, Radka, and Robert K. MacGregor. 2019. The Impact of the New EU Trademark Regime on Entrepreneurial Competitiveness. Forum Scientiae Oeconomia 7: 59-70.

MacGregor Pelikánová, Radka, and Robert K. MacGregor. 2020. The EU puzzling CSR regime and the confused perception by ambassadors of luxury fashion businesses: A case study from Pařižská. Central European Business Review 9: 74-108. [CrossRef] 
Mansell, Pau, Simon P. Philbin, and Efrosyni Konstantinou. 2020. Redefining the Use of Sustainable Development Goals at the Organisation and Project Levels-A Survey of Engineers. Administrative Sciences 10: 55. [CrossRef]

Mazzoni, Francesca. 2020. Circular economy and eco-innovation in Italian industrial clusters. Best practices from Prato textile cluster. Insights into Regional Development 2: 661-76. [CrossRef]

McDonald, Gael. 2009. An anthology of codes of ethics. European Business Review 21: 344-72. [CrossRef]

Meadows, Dennis L., Jørgen Randers, and William W. Behrens. 1972. The Limits to Growth. New York: Universe Books.

Melecký, Lukáš, and Michaela Staníčková. 2014. Regional Efficiency Evaluation by DEA Approach: Comparison of Selected EU15 and EU13 Countries. In Proceedings of the 2nd International Conference on European Integration (ICEI 2014). Ostrava: VSB-Technical University Ostrava, pp. 465-75.

Messikomer, Carla M., and Carlo C. Circa. 2010. Constructing a Code of Ethics: An Experiential Case of a National Professional Organization. Journal of Business Ethics 95: 55-71. [CrossRef]

Metzker, Zdenko, and Justas Streimikis. 2020. CSR activities in the Czech SME segment. International Journal of Entrepreneurial Knowledge 8: 49-64. [CrossRef]

Miłek, Dorota. 2018. Spatial differentiation in the social and economic development level in Poland. Equilibrium. Quarterly Journal of Economics and Economic Policy 13: 487-507.

Mohammadi, Massoud A. D., Abbas Mardani, Mohd Khan, and Dalia Streimikiene. 2018. Corporate sustainability disclosure and market valuation in a Middle Eastern Nation: Evidence from listed firms on the Tehran Stock Exchange: Sensitive industries versus non-sensitive industries. Economic Research-Ekonomska Istraživanja 31: 1488-511. [CrossRef]

Nicolaides, Angelo. 2016. Moral Intensity and Service Delivery in the Hospitality Industry: The Value of Codes of Ethics. Journal of Economics 7: 73-84. [CrossRef]

Oladinrin, Olugbenga T., and Christabel M. F. Ho. 2016. Critical enablers for codes of ethics implementation in construction organizations. Journal of Management in Engineering 32: 1-10. [CrossRef]

Olšanová, Květa, Gina Gook, and Marija Zlatić. 2018. Influence of Luxury Companies' Corporate Social Responsibility Activities on Consumer Purchase Intention: Development of Theoretical Framework. Central European Business Review 7: 1-25. [CrossRef]

Onyango, Joel, and Nora Ndege. 2020. Academic-Business Partnerships for SDGs: The Fourth Industrial Revolution in Africa. In Partnerships for the Goals. Encyclopedia of the UN Sustainable Development Goals. Edited by Filho W. Leal, A. M. Azul, L. Brandli, Salvia A. Lange and T. Wall. Cham: Springer.

Paksiova, Renáta. 2016. Reporting of non-financial information on companies in the context of sustainable development in Slovakia. In Účetnictvi a auditing v procesu světové harmonizace: Sbornik z [16.] mezinárodní vědecké konference: Vranov nad Dyjí. Praha: Vysoká škola ekonomická v Praze, Nakladatelství Oeconomica, pp. 153-60.

Patel, Zarina, Saskia Greyling, David Simon, Helen Arfvidsson, Nishendra Moodley, Natasha Primo, and Wright Carol. 2017. Local responses to global sustainability agendas: Learning from experimenting with the urban sustainable development goal in Cape Town. Sustainability Science 12: 785-97. [CrossRef]

Perez-Batres, Luis A., Jonathan P. Doh, Van V. Miller, and Michael J. Pisani. 2012. Stakeholder Pressures as Determinants of CSR Strategic Choice: Why do Firms Choose Symbolic Versus Substantive Self-Regulatory Codes of Conduct? Journal of Business Ethics 110: 157-72. [CrossRef]

Peters, Elisabeth, Tomáš Klieštik, Hussam Musa, and Pavol Durana. 2020. Product decision-making information systems, real-rime big data analytics, and deep learning-enabled smart process planning in sustainable Industry 4.0. Journal of Self-Governance and Management Economics 8: 16-22.

Pickard, Madeleine, Iulia Grecu, and Gheorghe Grecu. 2019. Sustainable Smart Manufacturing in Industry 4.0: Real-Time Resource Planning, Process Monitoring, and Production Control. Economics, Management, and Financial Markets 14: 30-36.

Pisani, Niccolò, Arno Kourula, Ank Kolk, and Renske Meijer. 2017. How global is international CSR research? Insights and recommendations from a systematic review. Journal of World Business 52: 591-614. [CrossRef]

Porter, Michael E., and Mark Kramer. 2011. The Big Idea: Creating Shared Value, Rethinking Capitalism. Harvard Business Review 89: 62-77.

Razminiene, Kristina. 2019. Circular economy in clusters' performance evaluation. Equilibrium. Quarterly Journal of Economics and Economic Policy 14: 537-59. 
Rickbaby, Mohammad A., Jacqueline Glass, and Scott Fernie. 2020. Conceptualizing the Relationship between Personal Values and Sustainability-A TMO Case Study. Administrative Sciences 10: 15. [CrossRef]

Rockström, Johan, Will Steffen, Kevin Noone, Åsa Persson, F. Stuart Chapin III, Eric Lambin, Timothy M. Lenton, Marten Scheffer, Carl Folke, Hans Joachim Schellnhuber, and et al. 2009. Planetary boundaries: Exploring the safe operating space for humanity. Ecology and Society 14: 32. [CrossRef]

Rodriguez-Fernandez, Mercedes. 2016. Social responsibility and financial performance: The role of good corporate governance. Business Research Quarterly 19: 137-51. [CrossRef]

Sachs, Jeffrey D. 2012. From millennium development goals to sustainable development goals. The Lancet 379: 2206-11. [CrossRef]

Sachs, Jeffrey D., Guido Schmidt-Traub, Christian Kroll, and David Durand-Delacre. 2016. Preliminary Sustainable Development Goal (SDG) Index and Dashboard. Sustainable Development Solutions Network 15. Available online: http://unsdsn.org/resources/publications/sdg-index/ (accessed on 20 March 2016).

Schaltegger, Stefan, Markus Beckmann, and Kai Hockerts. 2018. Collaborative Entrepreneurship for Sustainability: Creating Solutions in Light of the UN Sustainable Development Goals. International Journal of Entrepreneurial Venturing 10: 131-52. [CrossRef]

Schmidt, Frank L., and John E. Hunter. 2014. Methods of Meta-Analysis-Correcting Error and Bias in Research Findings, 3rd ed. London: SAGE, 640p. ISBN 978-145-228-689-1.

Semenenko, Inna, Ruslan Halhash, and Kseniia Sieriebriak. 2019. Sustainable development of regions in Ukraine: Before and after the beginning of the conflict. Equilibrium. Quarterly Journal of Economics and Economic Policy 14: 317-39. [CrossRef]

Silverman, David. 2013. Doing Qualitative Research - A Practical Handbook, 4th ed. London: SAGE. ISBN 978-1446260159.

Singh, Jatinder, Oriol Iglesias, and Jean Batista-Foguet. 2012. Does having an ethical brand matter? The influence of consumer perceived ethicality on trust, affect and loyalty. Journal of Business Ethics 111: 541-49. [CrossRef]

Sokolovska, Iskra, and Aaleksandr Kešeljević. 2019. Does sustainability pay off? A multi-factor analysis on regional DJSI and renewable stock indices. Economic Research-Ekonomska Istraživanja 32: 423-39. [CrossRef]

Sosik, John J., and Dongil Jung. 2018. Full Range Leadership Development: Pathways for People, Profit, and Planet. London and New Tork: Routledge.

Spaiser, Viktoria, Shyam Ranganathan, Ranjula Bali Swain, and David J. T. Sumpter. 2016. The sustainable development oxymoron: Quantifying and modelling the incompatibility of sustainable development goals. International Journal of Sustainable Development, and World Ecology 24: 457-70. [CrossRef]

Sroka, Włodzimierz, and Marketa Lőrinczy. 2015. The perception of ethics in business: Analysis of research results. Procedia Economics and Finance 34: 156-63. [CrossRef]

Sroka, Włodzimierz, and Richard Szántó. 2018. Corporate Social Responsibility and Business Ethics in Controversial Sectors: Analysis of Research Results. Journal of Entrepreneurship, Management and Innovation (JEMI) 14: 111-26. [CrossRef]

Statler, Matt, and David Oliver. 2016. The Moral of the Story: Re-framing Ethical Codes of Conduct as Narrative Processes. Journal of Business Ethics 136: 89-100. [CrossRef]

Steffen, Will, Katherine Richardson, Johan Rockström, Sarah E. Cornell, Ingo Fetzer, Elena M. Bennett, Reinette Biggs, Stephen R. Carpenter, Wim De Vries, Cynthia A. De Wit, and et al. 2015. Planetary boundaries: Guidinghuman development on a changing planet. Science 347: 1259855. [CrossRef] [PubMed]

Taylor, Charles. 2018. The Ethics of Authenticity. Cambridge: Harvard University Press.

Thacker, Scott, Daniel Adshead, Marianne Fay, Stéphane Hallegatte, Mark Harvey, Hendrik Meller, Nicholas O’Regan, Julie Rozenberg, Graham Watkins, and Jim W. Hall. 2019. Infrastructure for sustainable development. Nature Sustainability 2: 324-31. [CrossRef]

Tölkes, Christina, and Elias Butzmann. 2018. Motivating Pro-Sustainable Behavior: The Potential of Green Events-A Case-Study from the Munich Streetlife Festival. Sustainability 10: 3731. [CrossRef]

Trettin, Carol, George Lazaroiu, Iulia Grecu, and Gheorghe Grecu. 2019. The Social Sustainability of Citizen-centered Urban Governance Networks: Sensor-based Big Data Applications and Real-Time Decision-Making. Geopolitics, History, and International Relations 11: 27-33.

Turečková, Kamila, and Jan Nevima. 2019. Smart Approach in Regional Development. In Proceedings of MIRDEC-12th, International Academic Conference Multidisciplinary and Interdisciplinary Studies on Social Sciences. Rome: University of Washington Rome Center, pp. 77-84. ISBN 978-605-81247-7-6. 
Udell, Mitchell, Vojtech Stehel, Tomas Kliestik, Jana Kliestikova, and Pavol Durana. 2019. Towards a Smart Automated Society: Cognitive Technologies, Knowledge Production, and Economic Growth. Economics, Management, and Financial Markets 14: 44-49.

Van Tulder, Rob. 2017. Rescuing the Collaborative Paradigm from its Supporters? Annual Review of Social Partnerships 12: 27-31.

Van Tulder, Rob, and Nienke Keen. 2018. Capturing Collaborative Challenges: Designing Complexity-Sensitive Theories of Change for Cross-Sector Partnerships. Journal of Business Ethics 150: 315-32. [CrossRef] [PubMed]

Van Tulder, Rob, and Ans Kolk. 2001. Multinationality and Corporate Ethics: Codes of Conduct in the Sporting Goods Industry. Journal of International Business Study 32: 267-83. [CrossRef]

Van Tulder, Rob, May M. Seitanidi, Andrew Crane, and Stephen Brammer. 2016. Enhancing the Impact of Cross-Sector Partnerships. Four Impact Loops for Channeling Partnership Studies. Journal of Business Ethics 135: 1-17. [CrossRef]

Van Zanten, Jan Anton, and Rob Van Tulder. 2018. Multinational enterprises and the Sustainable Development Goals: An institutional approach to corporate engagement. Journal of International Business Policy 1: 208-33. [CrossRef]

Vogel, David. 2010. The Private Regulation of Global Corporate Conduct, Achievements and Limitations. Business E Society 49: 68-87.

Vu, Hieu M., and Vu M. Ngo. 2019. Strategy Development from Triangulated Viewpoints for a Fast Growing Destination toward Sustainable Tourism Development-A Case of Phu Quoc Islands in Vietnam. Journal of Tourism and Services 10: 117-40. [CrossRef]

Washburn, Nathan T., David A. Waldman, Mary F. Sully de Luque, and Min Z. Carter. 2018. Executives' Stakeholder Values in the Prediction of Work Process Change. Journal of Management Studies 55: 1423-51. [CrossRef]

Wattanakuljarus, Anan. 2019. Effects and burdens of a carbon tax scheme in Thailand. Eurasian Economic Review 9: 173-219. [CrossRef]

Weber, James, and David Wasieleski. 2013. Corporate ethics and compliance programs: A report, analysis and critique. Journal of Business Ethics 112: 609-26. [CrossRef]

Whitehouse, Ginny. 2010. Newsgathering and Privacy: Expanding Ethics Codes to Reflect Change in the Digital Media Age. Journal of Mass Media Ethics 25: 310-27. [CrossRef]

Zaušková, Anna, and Monika Rezníčková. 2020. SoLoMo marketing as a global tool for enhancing awareness of eco-innovations in Slovak business environment. Equilibrium. Quarterly Journal of Economics and Economic Policy 15: 133-50. [CrossRef]

Zhuravleva, Natalia A., Elvira Nica, and Pavol Durana. 2019. Sustainable Smart Cities: Networked Digital Technologies, Cognitive Big Data Analytics, and Information Technology-driven Economy. Geopolitics, History, and International Relations 11: 41-47.

Zikic, Srdjan. 2018. Modern concept of sustainable development. Progress in Economics Sciences 5: 143-51.

Zolingen, Simone J., and Hakan Honders. 2010. Metaphors and the Application of a Corporate Code of Ethics. Journal of Business Ethics 92: 385-400. [CrossRef]

Publisher's Note: MDPI stays neutral with regard to jurisdictional claims in published maps and institutional affiliations.

(C) 2020 by the authors. Licensee MDPI, Basel, Switzerland. This article is an open access article distributed under the terms and conditions of the Creative Commons Attribution (CC BY) license (http://creativecommons.org/licenses/by/4.0/). 